\title{
PENGARUH ESTEEM NEEDS TERHADAP NIAT BELI KONSUMEN DENGAN BRAND TRUST SEBAGAI VARIABEL MEDIASI
}

\author{
Pauline Geethruida Liwe ${ }^{1}$ \\ I Nyoman Nurcaya ${ }^{2}$ \\ ${ }^{1,2}$ Fakultas Ekonomi dan Bisnis Universitas Udayana, Bali, Indonesia \\ email: paulineliwe@gmail.com
}

\begin{abstract}
ABSTRAK
Penelitian berikut bertujuan untuk menganalisa pengaruh esteem needs terhadap niat beli konsumen dengan brand trust sebagai variabel mediasi (Studi Pada Produk Polo Ralph Lauren di Kota Denpasar). Penelitian dilaksanakan dengan tekhnik analisa data Path Analysis. Sampel didapatkan dengan memakai metode purposive sampling sejumlah 100 responden. Berdasar kepada hasil analisa bisa disimpulkan bahwasannya esteem needs berpengaruh positif serta signifikan pada niat beli konsumen. Esteem needs mempunyai pengaruh positif juga signifikan terhadap brand trust pelanggan. Brand trust mempunyai pengaruh positif serta signifikan terhadap niat beli konsumen. Brand trust memediasi pengaruh positif esteem needs terhadap niat beli konsumen. Saran yang bisa diberikan untuk produsen Polo Ralph Lauren haruslah memberikan perhatian pada konsumen tentang berguna tidaknya sebuah produk Polo Ralph Lauren hingga menjadi inspirasi serta memberi peningkatan esteem needs.
\end{abstract}

Kata kunci: esteem needs, brand trust, niat beli

\section{ABSTRACT}

The following research aims to analyze the effect of esteem needs on consumer purchase intentions with brand trust as a mediating variable. The research was conducted with Path Analysis data analysis techniques. The sample was obtained by using a purposive sampling method of 100 respondents. Based on the results of the analysis it can be concluded that the needs esteem has a positive and significant effect on consumers' purchase intention. Esteem needs have a significant positive influence on the customer's brand trust. Brand trust has a positive and significant influence on consumers' purchase intentions. Brand trust mediates the positive influence of esteem needs on consumer buying intentions. Suggestions that can be given to Polo producers Ralph Lauren must pay attention to consumers about whether or not a Polo Ralph Lauren product is useful to be an inspiration and give an increase in esteem needs.

Keywords: esteem needs, brand trust, purchase intention 


\section{PENDAHULUAN}

Pada era modern sekarang ini masyarakat cenderung dihadapkan pada berbagai pilihan gaya hidup atau dikenal dengan istilah lifestyle. Gaya hidup akan berpengaruh pada pola pikir, pola konsumsi, hingga pola fashion sehari-hari. Deviana (2014) menyatakan masyarakat modern cenderung mengubah gaya berpenampilan mereka dengan menyesuaikan trend saat ini, baik itu trend rambut, trend makanan, hingga trend berpakaian. Hal ini menyebabkan para konsumen cenderung memilih produk yang akan mereka beli, berdasarkan harga, merek, sampai pada produk yang baru diluncurkan atau "booming” (Saadia, 2013).

Pasar Indonesia saat ini dibanjiri dengan jenis barang dan jasa baik dari dalam maupun luar negeri yang terdiri atas berbagai macam merek (Amsyah, 2010). Berdasar potensial tersebut semakin bertambah brand terkenal serta mewah berkelas yang membangun toko di Indonesia juga makin membuat manja sifat consumerism rakyat Indonesia, merk seperti Polo Ralph Lauren, Louis Vuitton, Jimmy Choo, Prada, Bally, Christian Loubuttin, Versace. Perasaan butuh untuk barang-barang mewah serta lifestyle banyak masyarakat Kota Denpasar adalah sebuah hal yang wajib yang terjadi pada tiap-tiap pelanggan. Kejadian yang seperti itu telah ada sejak dulu sampai sekarang. Keadaan tersebut yang menjadi sebab semua pemilik merk barang mewah juga berkelas turut membuat ramai persaingan di Bali, seperti pada Kota Denpasar dengan tujuan bisa memberikan peningkatan omzet lewat penjualan barang-barang fashion yang dijual.

Pemakaian barang import berikutlah diperkirakan bisa memberi peningkatan esteem needs pelanggan. Teori Maslow (2002:97) Consumers esteem needs ialah rasa ingin pelanggan agar dipandang serta terlihat terhormat di mata orang lain saat melakukan perbelanjaan agar memakai sebuah barang atau jasa. Selain itu, consumers esteem needs pula sudah dipakai untuk hasil vital dikarenakan memiliki kaitan yang erat dengan keadaan psikologis manusia serta secara luas diyakini terdiri dari lebih dari kompetensi yang hanya dirasakan, dan ini menyebabkan tingkat relatif semakin tinggi atas keyakinan evaluasi juga kognisi. Ada beberapa indikator dalam variable yang dipakai (Deviana, 2014) itu adalah, selalu diinginkan agar orang lain hormati, mencari penghormatan diri serta merasakan kepentingan berhubungan dengan orang lainnya.

Untuk pelanggan yang berorientasi diri memilih tumpuan di prinsip, didalam proses pengambilan keputusan beli berdasar kepada rasa yakin (Ayu dan Kerti, 2014). Pengambilan keputusan dalam pembelian tidak juga dikarenakan mengikuti ataupun hanya agar dihargai atau dihormati, bisa dibilang tipe berikut cukup memiliki logika. Keputusan pembelian yang memiliki tumpuan emosi, pengambilan keputusan pembelian didominasi oleh pelanggan lainnya. Barangbarang dengan merk mewah biaanya jadi pilihan juga tak melewati sebuah proses pemikiran terlebih dahulu mengenai manfaatnya (Hanzaee \& Taghipourian, 2012). Citra merek berpengaruh positif signifikan terhadap niat beli (Darmawan dan Nurcaya, 2018).

Merk yang kuat memiliki kemampuan menarik minat pelanggan dalam melakukan pembelian barang yang mereka iginkan (Goenawan, 2014). Branding 
sangat vital untuk organisasi dalam menampilkan nilai barang yang akan dijual ke pasaran, tetapi merk tak memiliki arti bila tak mempunyai brand trust yang kuat untuk pasar (Amsyah, 2010). Menurut Kotler dan Armstrong (2012:263), Kepercayaan merek (brand trust) akan menentukan pembelian konsumen terhadap merek dan kepercayaan akan berpotensi menciptakan hubungan-hubungan yang bernilai tinggi (Hanzaee \& Taghipourian, 2012).

Kepercayaan konsumen pada merek yang beragam memberikan pengaruh positif terhadap niat beli konsumen (Dehdashti Shahrokh \& Deilami Azodi, 2013). Konsumen harus lebih mengidentifikasi dan memahami merek dari produk tersebut sebelum melakukan pembelian. Pilihan pelanggan untuk sebah merk produk memiliki ketergantungan pada kepercayaan merk yang lekat di benak konsumen (Hung et al., 2011). Organisasi haruslah bisa memberi yang paling baik cocok keperluan serta keinginan pelanggan serta organisasi juga haruslah membangun kepercayaan merk yang kuat dari pesaing mengenai produknya kepada pelanggan, agar organisasi tetap bisa mempertahankan pangsa pasarnya dan juga dapat mempengaruhi persepsi konsumen (Goenawan, 2014). Konsumen akan semakin yakin dengan pilihannya apabila memiliki kepercayaan pada merek, menyukai merek, serta menganggap merek tersebut sebagai bagian dari dirinya yang memberikan pengaruh positif pada niat beli konsumen (Andrie dan Harold, 2013).

Beberapa penelitian membuktikan variabel brand trust mempunyai pengaruh positif pada niat beli konsumen. Seperti contoh penelitian Ayu dan Kerti (2014) memberi pernyataan bahwa brand trust mempunyai pengaruh positif terhadap niat beli konsumen. Brand trust berpengaruh positif terhadap niat beli konsumen (Hanzaee \& Taghipourian, 2012). Penelitian lainnya memberi pernyataan bahwa brand trust berpengaruh positif terhadap niat beli konsumen (Dehdashti Shahrokh \& Deilami Azodi, 2013). Berbeda dengan penelitian yang mendapatkan hasil bahwa niat beli konsumen tidak dipengaruhi oleh brand trust dari suatu merek (Goenawan, 2014). Hasil yang sama diungkapkan oleh Rahmawati dalam penelitiannya menyatakan brand trust tidak berpengaruh positif terhadap niat beli konsumen (Setyaningsih et al., 2007).

Esteem needs merupakan salah satu penentu terjadinya kepercayaan merek atau brand trust. Pada diri konsumen esteem needs yang dapat diciptakan oleh suatu merek akan memberikan pengaruh positif dalam meningkatkan kepercayaan merek atau brand trust. Seperti contoh penelitian yang menyatakan bahwa esteem needs berpengaruh positif terhadap brand trust konsumen (Hanzaee \& Taghipourian, 2012). Ayu dan Kerti (2014) menyatakan bahwa brand trust memiliki hubungan positif terhadap esteem needs. Penelitian lain menyatakan bahwa esteem needs berpengaruh positif terhadap brand trust (Dehdashti Shahrokh \& Deilami Azodi, 2013). Berbeda dengan penelitian dari Kevin Goenawan yang menyatakan bahwa brand trust tidak dipengaruhi oleh esteem needs dari diri konsumen (Goenawan, 2014). Hal yang sama diungkapkan oleh peneliti lainnya yang mendahapatkan hasil brand trust tidak memiliki hubungan positif terhadap esteem needs (Setyaningsih et al., 2007).

Polo Ralph Lauren dipilih karena merupakan satu diantaran banyaknya brand yang diketahui dengan banyaknya tersedia varian-varian hingga pelanggan dapat makin termanjakan dalam memilih produk yang diinginkan juga cocok dengan 
kebutuhan. Tuntutan agar makin ikut dengan jaman didalam memakai pakaian jadi satu dari sekian pendorong semakin cepatnya proses membeli dari pelanggan yang tertarik terhadap merk Polo Ralph Lauren yang selalu ganti-ganti mode mengikuti tren yang sedang mereka pakai, contoh yang sering digunakan dalam produk sandang ialah negara barat dikarenakan dianggap sederhana, mewah juga modern dengan memakai merk Polo Ralph Lauren.

Kejadian tersebut memberikan gambaran bahwasannya kecenderungan pelanggan agar melakukan pembelian barang-barang mode terbaru dikarenakan kosumen mencari merk yang mereka pakai. Pelanggan memakai status barang sebagai simbol agar melakukan komunikasi pada sekelompok referensi yang mempunyai respon sangat vital untuk konsumen pembeli barang (Wibisono, 2012). Masyarakat di Indonesia seperti Bali baik pada wilayah kota ataupun di desa merupakan masyarakat yang memiliki tingkat konsumtif tinggi serta gengsi memberi peran cukup besar didalam konteks niat beli mereka, belum lagi warga wilayah kota yang memiliki gengsi lebih tinggi, hingga makin mahalnya barang yang ditawarkan makin banyak juga pembelinya. Tidaklah mengherankan Indonesia khususnya Bali jadi satu dari sekian tujuan utama export barang-barang dari luar negeri, karena masyarakat Indonesia merupakan pecinta barang-barang luar negri berdasar kepada gengsi di masyarakat.

Pemaparan masalah yang dipaparkan tersebut telah mendapat dukungan dengan penelitian-penelitian ilmiah serta teori tujuan daripada penelitian berikut yang ingin tercapai 1) Bagaimana pengaruh esteem needs pada niat beli pelanggan untuk pakaian Polo Ralph Lauren, 2) Bagaimana pengaruh esteem needs pada brand trust pelanggan untuk pakaian Polo Ralph Lauren, 3) Bagaimana pengaruh brand trust pada niat beli pelanggan untuk pakaian Polo Ralph Lauren, 4) Bagaimana peran brand trust memediasi pengaruh esteem needs pada niat beli pelanggan untuk pakaian Polo Ralph Lauren.

Persepsi adalah suaut proses yang haruslah dilewati oleh pelanggan dalam pemilihan, pengorganisasian, penginterpretasian stimulus didalam suatu gambar yang memiliki sifat koheren (Suprapti, 2010:68). Prilaku konsumen (consumer behavior) yaitu proses yang terjadi untuk pelanggan saat membuat keputusa dalam pembelian, apakah yang akan mereka beli, dimana, kapan, serta bagaimana proses belinya. Hingga bisa dibentuk kesimpulan bahwa prilaku pelanggan adalah sebuah proses yang memiliki kesinambungan.

Prilaku niat terdefinisi Mowen and Minor (2007) untuk rasa ingin pelanggan agar memiliki prilaku tertentu didalam mempunyai, membuang, serta memakai barang ataupun jasa. Pelanggan dapat memberi bentuk rasa inginnya dalam pencarian info, memberikan orang lainnya mengenai pengalaman dengan suatu barang, pembelian suatu barang ataupun jasa tertentu, ataupun membuang barang dengan cara tertentu.

Proses mengambil keputusan pelanggan dapat berbeda satu dengan yang lain, bergantung jenis keputusan membelinya. Proses membeli yang rumit serta mahal dapat memberi keterlibatan banyaknya pertimbangan yang dibutuhkan oleh proses membeli. Menurut Assael (Philip Kotler, 2007:221), ada beberapa prilaku melakukan proses membeli pelanggan berdasar kepada tingkat terlibat atau tidaknya pelanggan tingkat diferensiasinya, yaitu: Prilaku pembelian yang rumit 
yaitu pelanggan langsung memiliki keterlibatan didalam prilaku membeli yang rumit apabila mereka memiliki tingkat keterlibatan yang tinggi didalam proses membeli serta sadar dengan ada tidaknya perbedaan yang signifikan dibandingkan sekian merk yang ada, hal seperti berikut terjadi apabila barangnya mahal, jarang dibeli, memiliki risiko juga sangat memberikan ekspresi pada pribadinya. Prilaku pembelian pengurang ketidaknyamanan/ disonasi yaitu prilaku pembelian berikut pelanggan jadi sangatlah terlibat didalam suatu proses membeli, tetapi hanya beberapa perbedaan dalam berbagai merk yang dilihat. Prilaku membeli dikarenakan biasa yaitu prilaku proses membeli tersebut ada apabila terdapat proses membeli barang atau jasa dengan tingkat terlibatnya pelanggan sangat rendah, serta ada tidaknya merk berbeda yang signifikan. Prilaku membeli dengan mencari-cari varians yaitu pada perilaku tersebut keadaan membeli diberi tanda oleh ada tidaknya terlibat sangat rendah oleh pelanggan, tetapi adanya merk berbeda yang signifikan.

Menurut Undang-Undang Merek No. 15 Tahun 2001 pasal 1 ayat 1 merek adalah tanda yang memiliki rupa gambar, nama, kata, huruf-huruf, angka-angka, susunan warna, ataupun kombinasi daripada unsur yang telah disebut yang mempunyai daya pembeda serta dipakai didalam kegiatan perdagangan barang maupun jasa. Kepercayaan merek adalah persepsi akan kehandalan dari sudut pandang konsumen didasarkan pada pengalaman, atau lebih pada urutan-urutan transaksi atau interaksi yang dicirikan oleh terpenuhinya harapan akan kinerja produk dan kepuasan. Dalam kepercayaan merek, terdapat beberapa faktor yang dapat digunakan sebagai dasar terciptanya brand trust serta faktor-faktor yang dapat dijadikan sebagai dasar pengukuran dari kepercayaan tersebut. Menurut Kotler dan Keller (2007:5), terdapat tiga faktor yang dapat mempengaruhi kepercayaan terhadap suatu merek, yaitu brand characteristics, company characteristics, dan consumer brand characteristics.

Suprapti (2010:68) persepsi merupakan sebuah proses yang harus dilalui oleh konsumen untuk memilih, mengorganisasi, menginterpretasi stimuli ke dalam sebuah gambaran yang bersifat koheren. Menurut Mangkunegara (2011:21) "Perilaku konsumen didefinisikan sebagai tindakan individu yang secara langsung terlibat dalam usaha memperoleh dan menggunakan barang-barang serta jasa ekonomis termasuk proses pengambilan keputusan yang mendahului dan menentukan tindakan-tindakan tersebut". Perilaku konsumen (consumer behavior) adalah proses yang terjadi pada konsumen ketika memutuskan untuk membeli, apa yang dibeli, dimana, kapan, dan bagaimana membelinya. Sehingga, dapat disimpulkan bahwasanya perilaku konsumen merupakan suatu proses yang terusmenerus (berkesinambungan). Berdasarkan beberapa pendapat tersebut dapat disimpulkan bahwa perilaku konsumen adalah semua kegiatan, tindakan serta proses psikologis yang mendorong tindakan tersebut pada saat sebelum membeli, ketika membeli, menggunakan produk dan jasa setelah melakukan hal-hal tersebut diatas atau kegiatan mengevaluasi.

Pavlou (2003) dalam niat untuk bertransaksi, dapat didefinisikan sebagai niat konsumen untuk terlibat dalam berbagai hubungan pertukaran online dengan penjual pada suatu web, seperti berbagi informasi bisnis, menjaga hubungan bisnis, dan melakukan transaksi bisnis. Didalam konsep B2C e-commerce, konsumen 
memerlukan niat untuk menentukan penjual online mana yang dipilih, website untuk mendapatkan dan memberikan informasi dan kemudian menyelesaikan transaksi dengan membeli produk atau jasa tersebut. Pavlou (2003) juga menjelaskan bahwa dalam bertransaksi online terdapat dimensi yang unik, dimana konsumen harus secara aktif terlibat dalam suatu penggunaan teknologi dan adanya interaksi dengan penjual online, pemisahan antara konsumen dan penjual online melalui webstore juga meningkatkan kekhawatiran yang timbul dari suatu produk yang identitasnya tidak pasti, dan ada kekhawatiran mengenai kelayakan internet itu sendiri dan infrastruktur terkait dimana hanya website sebagai media untuk berinteraksi dengan konsumen (misalnya, suatu infrastruktur yang lemah menimbulkan ketakutan bahwa pihak ketiga atau hacker dapat mengancam privasi dan informasi keuangan konsumen terkait). Perilaku niat didefinisikan Mowen and Minor (2007) sebagai keinginan konsumen untuk berperilaku menurut cara tertentu dalam rangka memiliki, membuang, dan menggunakan produk atau jasa. Jadi konsumen dapat membentuk keinginan untuk mencari informasi, memberitahukan orang lain tentang pengalamannya dengan sebuah produk, membeli sebuah produk atau jasa tertentu, atau membuang produk dengan cara tertentu.

Pengambilan keputusan konsumen akan berbeda-beda, tergantung pada jenis keputusan pembelian. Pembelian yang rumit dan mahal akan melibatkan lebih banyak pertimbangan yang diperlukan oleh pembelian. Menurut Assael (Philip Kotler, 2007:221), terdapat empat jenis perilaku pembelian konsumen berdasarkan tingkat keterlibatan pembeli dan tingkat diferensiasi mereka, yaitu: 1) Perilaku pembelian yang rumit : konsumen terlibat dalam perilaku pembelian yang rumit bila mereka sangat terlibat dalam pembelian dan sadar akan adanya perbedaan yang signifikan diantara berbagai merek, dimana ini terjadi bila produknya mahal, jarang dibeli, berisiko dan sangat mengekspresikan kepribadian, 2) Perilaku pembelian pengurang ketidaknyamanan/ disonasi : pada perilaku pembelian ini konsumen menjadi sangat terlibat dalam sebuah pembelian, namun melihat sedikit perbedaan diantara berbagai merek. Keterlibatan yang tinggi disadari adanya kenyataan bahwa pembelian tersebut mahal, jarang dilakukan dan berisiko. Setelah pembelian biasanya akan muncul ketidaksesuaian atau disonasi dari pengamatan terhadap hal-hal yang mengganggu mengenai produk yang dibeli atau kabar tentang hal-hal yang menyenangkan mengenai produk-produk sejenis lainnya, 3) Perilaku pembelian karena kebiasaan : perilaku pembelian ini terjadi bila terdapat pembelian produk dengan tingkat keterlibatan konsumen yang rendah, serta adanya perbedaan merek yang signifikan. Konsumen akan melakukan pembelian dengan mengambil merek tertentu secara berulang-ulang dimana hal tersebut dilakukan lebih karena kebiasaan daripada adanya kesetiaan terhadap suatu merek tertentu, 4) Perilaku pembelian yang mencari variasi : pada perilaku ini situasi pembelian ditandai oleh adanya keterlibatan yang rendah oleh konsumen, namun terdapat perbedaan merek yang signifikan. Situasi ini akan menyebabkan konsumen sering melakukan peralihan ke merek lain dan perpindahan merek ini biasanya karena mencari variasi dan bukan karena ketidakpuasan.

Asosiasi Pemasar Amerika (Kotler dan Amstrong, 2012) mendefinisikan merek sebagai nama, istilah, tanda, simbol, atau rancangan, atau kombinasi dari semuanya, yang dimaksudkan untuk mengidentifikasikan barang atau jasa atau 
kelompok penjualan dan untuk mendiferensiasikannya dari barang dan jasa pesaing. Menurut Undang-Undang Merek No. 15 Tahun 2001 pasal 1 ayat 1 merek merupakan tanda yang berupa gambar, nama, kata, huruf-huruf, angka-angka, susunan warna, atau kombinasi dari unsur-unsur tersebut yang memiliki daya pembeda dan digunakan dalam kegiatan perdagangan barang dan jasa. Kepercayaan terbangun karena adanya harapan bahwa pihak lain akan bertindak sesuai dengan kebutuhan dan keinginan konsumen. Selain itu Ria dan Gatot (2014) kepercayaan merek adalah kemampuan merek untuk dipercaya (brand reliability), yang bersumber pada keyakinan konsumen bahwa produk tersebut mampu memenuhi nilai yang dijanjikan dan intensi baik merek (brand intention) yang didasarkan pada keyakinan konsumen bahwa merek tersebut mampu mengutamakan kepentingan konsumen. Kepercayaan pelanggan pada merek (brand trust) didefinisikan sebagai keinginan pelanggan untuk bersandar pada sebuah merek dengan resiko-resiko yang dihadapi karena ekspektasi terhadap merek itu akan menyebabkan hasil yang positif (Thiripurasundari and Natarajan, 2011).

Menurut Rangkuti (2004: 23), brand trust dapat diukur melalui dimensi viabilitas (dimension of viability) dan dimensi intensionalitas (dimension of intentionality). Dimension of Viability. Dimensi ini mewakili sebuah persepsi bahwa suatu merek dapat memenuhi dan memuaskan kebutuhan dan nilai konsumen. Dimensi ini dapat diukur melalui indikator kepuasan dan nilai (value). Dimension of Intentionality. Dimensi ini mencerminkan perasaan aman dari seorang individu terhadap suatu merek. Dimensi ini dapat diukur melalui indikator security dan trust. Menurut Kotler \& Amstong (2012: 112) brand trust memiliki pengaruh yang sangat besar terhadap keberlangsungan sebuah merek, karena jika sebuah merek sudah tidak dipercayai lagi oleh konsumen maka produk dengan merek tersebut akan sulit untuk berkembang di pasar. Namun sebaliknya jika merek tersebut dipercayai oleh konsumen, maka produk dengan merek tersebut akan dapat terus berkembang di pasar. Dari pemaparan di atas dapat disimpulkan bahwa kepercayaan merek adalah kesediaan konsumen untuk mempercayai suatu merek dengan segala resikonya karena adanya harapan di benak mereka bahwa merek tersebut akan memberikan hasil yang positif kepada konsumen sehingga akan menimbulkan kesetiaan terhadap suatu merek.

Dalam kehidupan seseorang pasti akan berusaha untuk memenuhi kebutuhannya, baik dalam kebutuhan fisik, kebutuhan makanan, kebutuhan sosial, kebutuhan penghargaan, maupun dalam kebutuhan aktualisasi diri. Menurut Abraham Maslow orang akan berusaha memuaskan dulu kebutuhan mereka yang paling penting, jika seseorang berhasil memuaskan kebutuhan yang penting kemudian dia akan berusaha memuaskan kebutuhan yang terpenting berikutnya (Kotler dan Keller, 2007:227). Kelima tingkat kebutuhan manusia dalam hirarki kebutuhan Maslow saling berhubungan. Kebutuhan yang berada ditingkat bawah, bila sudah terpenuhi akan memicu kebutuhan di tingkat atas kenyamanan (http://ajiewahyujati.wordpress.com). Dalam hirarki kebutuhan Maslow, gengsi berada di dalam urutan yang keempat yang berarti bahwa kebutuhan mulai dari tingkatan pertama sampai ketiga kebutuhan manusia sudah terpenuhi. Dalam hal ini adalah pengguna pakaian merek Polo Ralph Lauren. Tindakan seseorang yang termotivasi akan dipengaruhi oleh persepsinya terhadap situasi tertentu. Persepsi 
adalah proses yang digunakan oleh individu untuk memilih, mengorganisasi, dan menginterpretasikan masukan informasi guna menciptakan gambaran dunia yang memiliki arti (Kotler dan Keller, 2007:228)

Beberapa penelitian membuktikan variabel harga diri ataupun esteem needs dapat memberi pengaruh positif pada niat beli pelanggan (Deviana, 2014). Harga diri ataupun esteem needs yang dipunya pelanggan memberi pengaruh positif signifikan pada niat beli konsumen untuk barang atau jasa (Johan, 2010). Penelitian lainnya memberi pernyataan bahwasannya niat beli satu orang dapat diberikan pengaruh secara positif signifikan oleh harga diri ataupun esteem needs yang mereka punya (Hung et al., 2011). Berbeda dengan riset Kambiz dan Mohammad yang menyatakan niat beli konsumen tidak dipengaruhi oleh esteem needs yang dimiliki konsumen (Hanzaee \& Taghipourian, 2012). Hal yang sama diungkapkan oleh Zohreh dalam penelitiannya yang memperoleh hasil esteem needs tidak memiliki pengaruh positif pada niat beli pelanggan (Dehdashti Shahrokh \& Deilami Azodi, 2013). Berdasar kepada hasil-hasil riset itu, dapat dibentuk sebuah hipotesa pertama seperti berikut:

$\mathrm{H}_{1}$ : esteem needs mempengaruhi niat beli konsumen secara positif.

Banyak penelitian yang membahas mengenai pengaruh esteem needs terhadap brand trust seperti penelitian yang memperoleh hasil bahwa esteem needs berpengaruh positif terhadap brand trust konsumen (Hanzaee \& Taghipourian, 2012). Penelitian lainnya menyatakan bahwa brand trust memiliki hubungan positif terhadap esteem needs (Prabhawedasattya, 2014). Penelitian berikutnya mendapatkan hasil bahwa esteem needs berpengaruh positif terhadap brand trust (Dehdashti Shahrokh \& Deilami Azodi, 2013). Berbeda dengan penelitian Kevin Goenawan yang mendapatkan hasil brand trust tidak dipengaruhi oleh esteem needs dari diri konsumen (Goenawan, 2014). Hal yang sama diungkapkan penelitian yang dilakukan oleh Rahmawati yang menyatakan brand trust tidak memiliki hubungan positif terhadap esteem needs (Setyaningsih et al., 2007). Berdasarkan pemahaman tersebut dapat dirumuskan hipotesis kedua sebagai berikut.

$\mathrm{H}_{2}$ : esteem needs mempengaruhi brand trust konsumen secara positif.

Brand trust yang kita terapkan bisa memberi akibat yang positif serta signifikan didalam membentuk niat beli pelanggan (Sudomo, 2013). Hasil yang sama juga disampaikan oleh penelitian lainnya yaitu brand trust pada konsumen mampu menciptakan dampak positif signifikan terhadap niat beli konsumen (Wibisono, 2012). Begitu pula dengan hasil yang diungkapkan oleh Andrie dan Harold (2013) brand trust pada suatu produk memberikan pengaruh positif terhadap niat beli konsumen. Berbeda dengan penelitian lain yang dilaksanakan di tahun 2014 dimana niat beli konsumen tidak dipengaruhi oleh brand trust dari suatu merek (Goenawan, 2014). Hal yang sama diungkapkan oleh penelitian lainnya yang menyatakan bahwa brand trust tidak memiliki pengaruh positif terhadap niat beli konsumen (Setyaningsih et al., 2007). Berdasar kepada paparan tersebut diatas bisa dibentuk suatu hipotesa ketiga seperti berikut.

$\mathrm{H}_{3}$ : brand trust mempengaruhi niat beli konsumen secara positif.

Penelitian yang meneliti mengenai bagaimana peran brand trust dalam memediasi pengaruh esteem needs terhadap niat beli konsumen seperti penelitian berikut yang menyatakan bahwa niat beli konsumen sangatlah terpengaruh dengan 
positif serta signifikan dengan adanya esteem needs ataupun harga diri pelanggan dengan ada atau tidaknya kepercayaan atau brand trust pada suatu barang atau jasa (Darmasari \& Wijayanto, 2014). Deviana (2014) memberikan bukti hal yang sama dengan ada tidaknya kepercayaan atau brand trust bisa memberi pengaruh positif signifikan dalam hubungan esteem needs dengan niat beli konsumen pada barang atau jasa. Penelitian lain memperoleh hasil bahwa pengaruh positif esteem needs dengan niat beli pelanggan di barang terbentuk dengan moderasi oleh kepercayaan atau brand trust pada suatu produk (Hanzaee \& Taghipourian, 2012). Berbeda dengan penelitian yang dilakukan di tahun 2014 menyatakan bahwa niat beli konsumen dipengaruhi oleh esteem needs tidak diperkuat oleh brand trust (Goenawan, 2014). Hal yang sama diungkapkan oleh penelitian sebelumnya di tahun 2007 yang menyatakan bahwa esteem needs memiliki hubungan positif terhadap niat beli konsumen yang tidak diperkuat oleh brand trust (Darmasari \& Wijayanto, 2014). Berdasarkan hasil penelitian tersebut, diajukan hipotesis ke empat yaitu.

$\mathrm{H}_{4}$ : brand trust memediasi pengaruh esteem needs terhadap niat beli konsumen secara positif.

Model konseptual berikut memberi penjelasan bahwasannya brand trust melakukan mediasi pengaruh positif esteem needs pada niat beli pelanggan. Untuk lebih jelasnya kerangka pemikiran dapat dilihat pada Gambar 1. pada halaman selanjutnya. Berdasarkan penelusuran path analisis dan hasil-hasil penelitian terdahulu maka model penelitian dapat digambarkan seperti berikut:

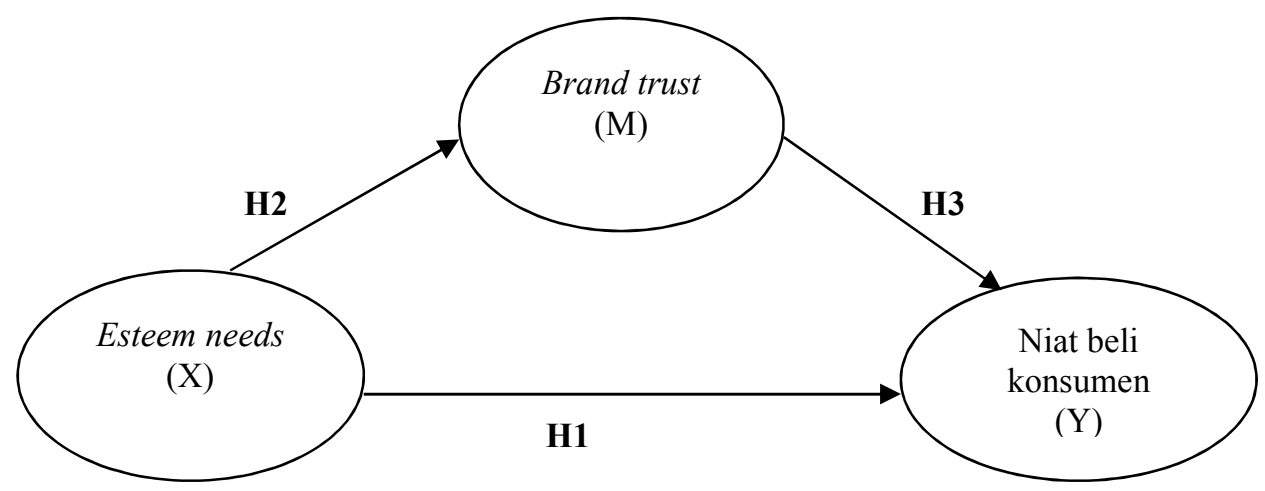

\section{Gambar 1. Kerangka Konseptual}

Sumber: Data Diolah, 2018

\section{METODE PENELITIAN}

Penelitian berikut memakai metode asosiatif yang memiliki tujuan untuk mengetahui pengaruh atau juga hubungan diantara dua variable ataupun lebih (Sugiyono, 2013:56). Riset ini dilaksanakan di Kota Denpasar. Kota Denpasar terpilih dikarenakan lokasi tersebut adalah pusat perkotaan dengan pertumbuhan sektor ekonomi warganya yang pesat, warga dengan jumlah padat serta populasi yang besar. Namun terlihat dari hal teknis, lokasi tersebut lolos semua kriteria yang dianggap efektif serta efisien didalam penyelenggaraan riset yang sesuai. Berdasarkan hasil wawancara awal dengan dua puluh konsumen yang berbelanja di Polo Ralph Lauren ditemukan permasalahan yang menyangkut dengan esteem 
needs, brand trust, seperti konsumen mementingkan persepsi orang lain apabila memakai produk Polo Ralph Lauren. Konsumen memiliki harapan yang ingin dipenuhi oleh Polo Ralph Lauren apabila membeli produknya. Karyawan pada Polo Ralph Lauren masih belum memiliki integritas dalam memberikan layanan, seperti kurangnya perhatian pada konsumen dalam memilih produk Polo Ralph Lauren. Konsumen yang membeli produk Polo Ralph Lauren berdasarkan prestige di mata orang lain.

Objek didalam riset merupakan sebuah hal ataupun apa sajakah yang jadi perhatian serta apa sajakah yang dilakukan penelitian. Objek didalam penelitian berikut yaitu brand trust memediasi esteem needs terhadap niat beli konsumen pada produk Polo Ralph Lauren di Kota Denpasar. Variabel bebas adalah manajemen bakat ekuitas merek dan esteem need $(\mathrm{X})$, brand trust $(\mathrm{M})$ dan variable dependennya yaitu niat beli konsumen (Y). Jenis data kuantitatif serta kualitatif yang digunakan dalam penelitian berikut yaitu data jumlah pegawai, jawaban responden pada kuesioner juga hal-hal menyangkut sejarah organisasi, struktur perusahaan serta aktivitas organisasi. Sumber data primer juga sekunder yang digunakan contohnya observasi juga memberikan kuisioner pada responden juga sejarah pendirian organisasi, struktur organisasi perusahaan, serta banyaknya pegawai.

Populasi didalam riset berikut yaitu pelanggan yang sesuai dengan kriteria yang cocok dengan riset niat beli pelanggan pada barang Polo Ralph Lauren. Metode penentuan sampel yang digunakan dalam penelitian ini adalah non probability sampling dengan jumlah sampel sebanyak 100 responden. Uji validitas memberi pernyataan suatu instrument dinyatakan valid apabila item yang memiliki korelasi positif dengan kriteria (skor total) juga korelasi besar memberi petunjuk bahwasannya item itu memiliki validasi yang besar juga. Syarat minimal agar dapat lolos syarat ialah apabila $r=0,3$ ". Uji reabilitas ditampilkan dengan angka indek yang menghitung konsistens tidaknya sebuah alat ukur didalam melakukan pengukuran gejala-gejala yang sesuai. Pengujian reliabilitas dapat memberi petunjuk sampai mana instrumen bisa kita percaya serta dapat kita harapkan. Nilai sebuah intrument dapat dibilang reliabel apabila nilai Alpha Cronbach $\geq 0,6$.

Teknik analisis data yang dipakai didalam riset berikut yaitu tehnik analisa jalur (path analysis). Path analysis adalah pengembangan daripada analisa regresi linier berganda, yang dipakai untuk memberi taksiran hubungan kausalitas antara variable yang berjenjang berdasarkan teori (Utama, 2007:135).

Pengaruh langsung esteem needs (X) terhadap brand trust $(\mathrm{M})$ dapat ditampilkan oleh koefisien jalur $\beta_{1}$, pengaruh langsung esteem needs $(\mathrm{X})$ pada niat beli konsumen (Y) ditampilkan oleh koefisien jalur $\beta_{3}$, serta pengaruh brand trust (M) pada niat beli konsumen (Y) ditampilkan oleh koefisien jalur $\beta_{2}$. Pengaruh tidak langsung esteem needs (X) terhadap niat beli konsumen (Y) didapatkan dengan melakukan perkalian $\beta_{1}$ dengan $\beta_{2}$.

Analisis jalur membutuhkan dilakukannya memeriksa validitas model. Benar atau tidaknya sebuah hasil analisa bergantung daripada dipenuhinya ataupun tidak asumsi-asumsi yang menjadi landasan didalam analisis jalur. Adapun indikator dalam analisis jalur adalah koefisien determinasi total. Koefisien determinasi total adalah total keberagaman data yang dapat dibuat sebuah rumusan sebagai berikut: 


$$
\mathrm{R}^{2} \mathrm{~m}=1-\left(\mathrm{e}_{1}\right)^{2}\left(\mathrm{e}_{2}\right)^{2}
$$

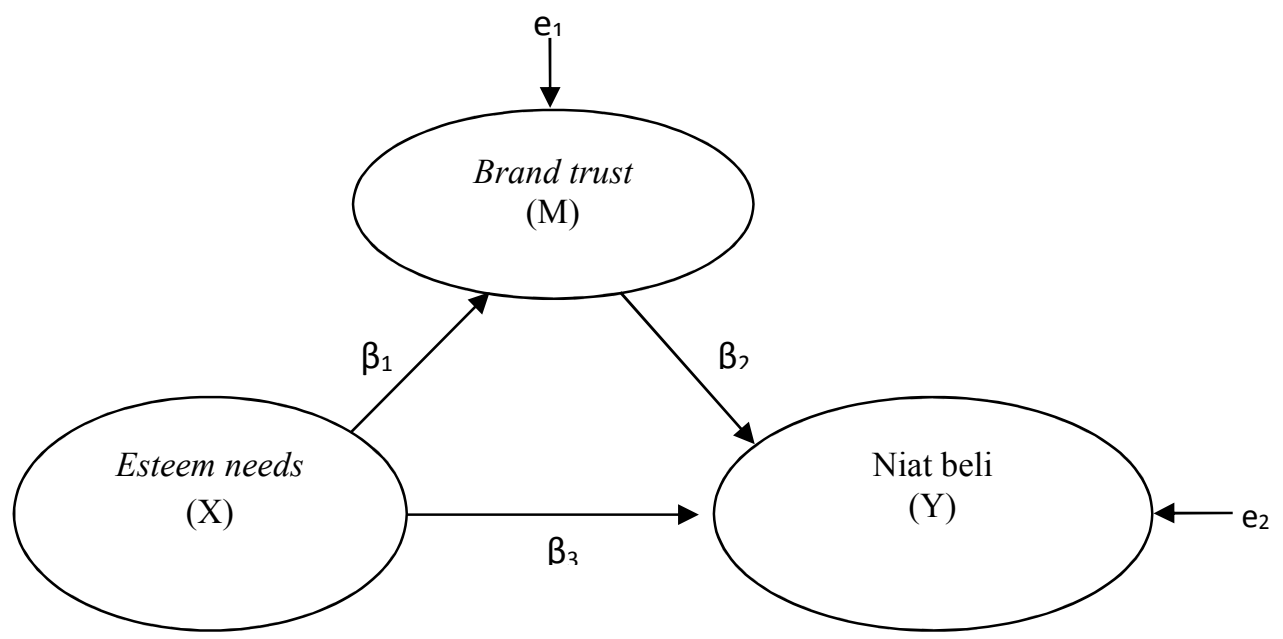

\section{Gambar 2. Diagram Jalur Penelitian}

Sumber: Data Diolah, 2018

Didalam pengujian signifikan atau tidaknya peran variabel brand trust memediasi dipakai rumus Sobel. Berdasar kepada pelaporan persamaan hasil regresi struktur 1 dan regresi struktur 2 untuk menguji signifikansi pengaruh tidak langsung maka menghitung nilai $\mathrm{z}$ dari koefisien ab dengan rumus sebagai berikut:

$$
z=\frac{a b}{S a b}
$$

VAF merupakan ukuran seberapa variabel pemediasi mampu menyerap pengaruh langsung yang sebelumnya signifikan dari model tanpa pemediasi. VAF dihitung dengan perhitungan sebagai berikut :

$$
V A F=\frac{(P 1 \times P 3)}{P 2+(P 1 \times P 3)}
$$

Jika nilai VAF diatas $80 \%$ maka peranan brand trust (M) sebagai pelaku mediasi secara penuh (full mediation). Apabila VAF memiliki nilai diantara 20\% $80 \%$ jadi bisa dimasukkan dalam kategori pelaku mediasi parsial (partial mediation), apabila kurang daripada $20 \%$ peneliti bisa membentuk sebuah kesimpulan bahwasannya hampir tak adanya efek mediasi (Hair et al., 2014).

\section{HASIL DAN PEMBAHASAN}

Kota Denpasar merupakan pusat kota dan pusat kegiatan bisnis yang memiliki pertumbuhan ekonomi yang cepat di Bali, perkembangan penduduk dengan jumlah yang tinggi dan laju pembangunan disegala bidang sehingga mengalami peningkatan secara rasional serta memberikan dampak terhadap pertumbuhan perekonomian. Dengan jumlah penduduknya yang dinamis memiliki berbagai ragam keinginan, gaya hidup yang berbeda-beda menjadi peluang bisnis yang sangat potensial bagi penyedia jasa belanja terutama produk fashion. Mengingat 
akan kebutuhannya yang semakin bertambah seiring perkembangan zaman, masyarakat Kota Denpasar selalu mengandalkan berbagai cara dalam memenuhi kebutuhan hidupnya agar bisa bergaya up to date setiap harinya. Kota Denpasar sebagai pusat perekonomian dan fashion di Provinsi Bali memiliki mall-mall besar yang menawarkan segala macam produk berkualitas tinggi. Salah satu mall di Bali yang menawarkan produk pakaian Polo Ralph Lauren yaitu Beachwalk Bali. Sogo, Nusa Dua - Bali menawarkan pakaian dan tas wanita maupun pria dan masih banyak lagi tempat lainnya yang menjual produk Polo Ralph Lauren, sehingga sampai saat ini produk Polo Ralph Lauren masih dapat bersaing dipasaran untuk merebut minat konsumen melakukan pembelian.

Uji validitas memberi pernyataan suatu instrument dinyatakan valid apabila item yang memiliki korelasi positif dengan kriteria (skor total) juga korelasi besar memberi petunjuk bahwasannya item itu memiliki validasi yang besar juga. Syarat minimal agar dapat lolos syarat ialah apabila $r=0,3$ ". Tabel 1 pada halaman berikutnya, dapat kita ketahui bahwasannya masing-masing indikator variable mempunyai besaran person correlation melebihi daripada 0,30 , jadi hal tersebut memiliki arti indikator/pertanyaan yang dipakai layak diaplikasikan dalam proses pengukuran variabel yang haruslah dilakukan pengukuran serta bisa mengungkapkan data daripada variable yang sedang dilakukan penelitian dengan tepat.

Tabel 1.

Rangkuman Hasil Uji Validitas

\begin{tabular}{cllcc}
\hline No & Variabel & Indikator & Korelasi & Keterangan \\
\hline 1) & Esteem Needs $(\mathrm{X})$ & Persepsi & 0,710 & Valid \\
& & Dihargai & 0,705 & Valid \\
& & Dihormati & 0,726 & Valid \\
& & Dikagumi & 0,775 & Valid \\
2) & \multirow{2}{*}{ Brand trust $(\mathrm{M})$} & Achieving result Acting & 0,845 & Valid \\
& & with integrity & 0,652 & Valid \\
& & Demonstrate concern & 0,845 & Valid \\
3) & Niat Beli (Y) & Pertimbangan & 0,782 & Valid \\
& & Kemantapan & 0,811 & Valid \\
& & Kecepatan & 0,870 & Valid \\
\hline
\end{tabular}

Sumber: Data diolah, 2018

Uji reliabilitas ditampilkan dengan angka indek yang menghitung konsistens tidaknya sebuah alat ukur didalam melakukan pengukuran gejala-gejala yang sesuai. Pengujian reliabilitas dapat memberi petunjuk sampai mana instrumen bisa kita percaya serta dapat kita harapkan. Nilai sebuah intrument dapat dibilang reliabel apabila nilai Alpha Cronbach $\geq 0,6$.

Table 2. disimpulkan bahwasannya besaran Cronbach's Alpha pada tiap-tiap variable $>0,6$, hal tersebut memiliki arti alat pengukuran itu dapat memberi hasil yang konsisten bila alat pengukuran itu dipakai lagi dalam melakukan penelitian untuk objek yang persis sesuai. Daripada model jalur yang terbentuk, ada beberapa persamaan struktural ataupun sistim persamaan simultan. 
Tabel 2.

Hasil Uji Reliabilitas

\begin{tabular}{llccc}
\hline No & & Variabel & $\begin{array}{c}\text { Cronbach's } \\
\text { Alpha }\end{array}$ & Keterangan \\
\hline 1$)$ & Esteem Needs $(\mathrm{X})$ & 0,704 & Reliabel \\
2) & Brand trust $(\mathrm{M})$ & 0,678 & Reliabel \\
$3)$ & Niat Beli(Y) & 0,757 & Reliabel \\
\hline
\end{tabular}

Sumber: Data diolah, 2018

Tabel 3.

Persamaan Hasil Regresi Struktur 1 Pengaruh X terhadap M

M

$0.730 \mathrm{X}$

\begin{tabular}{cc} 
Std. Error & 0,051 \\
$\mathrm{t}$ & 10.583 \\
Sig. $\mathrm{t}$ & 0,000 \\
R Square & 0,533 \\
F Hitung & 112,009 \\
Signifikansi F & 0,000 \\
\hline
\end{tabular}

Sumber: Data diolah, 2018

Tabel 3. memberikan penjelasan hasil pengujian pengaruh variable esteem needs $(\mathrm{X})$ pada brand trust $(\mathrm{M})$ diberikan penjelasan bahwasannya esteem needs memiliki pengaruh positif signifikan pada brand trust dengan nilai standardized coefficients beta senilai 0,543 serta nilai sig t senilai $0,000<0,05$.

Tabel 4. memberikan penjelasan hasil menguji pengaruh variable esteem needs $(\mathrm{X})$ pada niat beli konsumen $(\mathrm{Y})$ diberikan penjelasan bahwasannya esteem needs memiliki pengaruh positif signifikan pada niat beli konsumen dengan besaran standardized coefficients beta senilai 0,504 serta besaran sig t sejumlah $0,000<$ 0,05 .

Hasil dilakukannya uji pengaruh variable brand trust (M) pada niat beli konsumen (Y) diberi penjelasan bahwasannya brand trust memiliki pengaruh positif signifikan pada niat beli konsumen dengan besaran standardized coefficients beta senilai 0,347 serta besaran sig t sejumlah $0,001<0,05$. 
Output hasil SPSS uji pengaruh variable esteem needs (X) pada niat beli konsumen $(\mathrm{Y})$ dengan mediasi brand trust $(\mathrm{M})$ tergambar dengan model diagram jalur yang terpampang pada Gambar 3 pada halaman selanjutnya.

Tabel 4.

Persamaan Hasil Regresi Struktur 2 Pengaruh X, M terhadap Y

\begin{tabular}{cll}
\hline Model & \multicolumn{1}{l}{ Nilai } \\
\hline Y & $0.574 \mathrm{X}+0.293 \mathrm{M}$ \\
Std. Error & 0,076 & 0.102 \\
$\mathrm{t}$ & 6.652 & 3.399 \\
Sig. t & 0,000 & 0.001 \\
R Square & 0,726 & \\
F Hitung & 95,168 \\
Signifikansi F & 0,000 \\
\hline Sumber: Data diolah, 2018 &
\end{tabular}

Gambar 3. Model Diagram Jalur Akhir

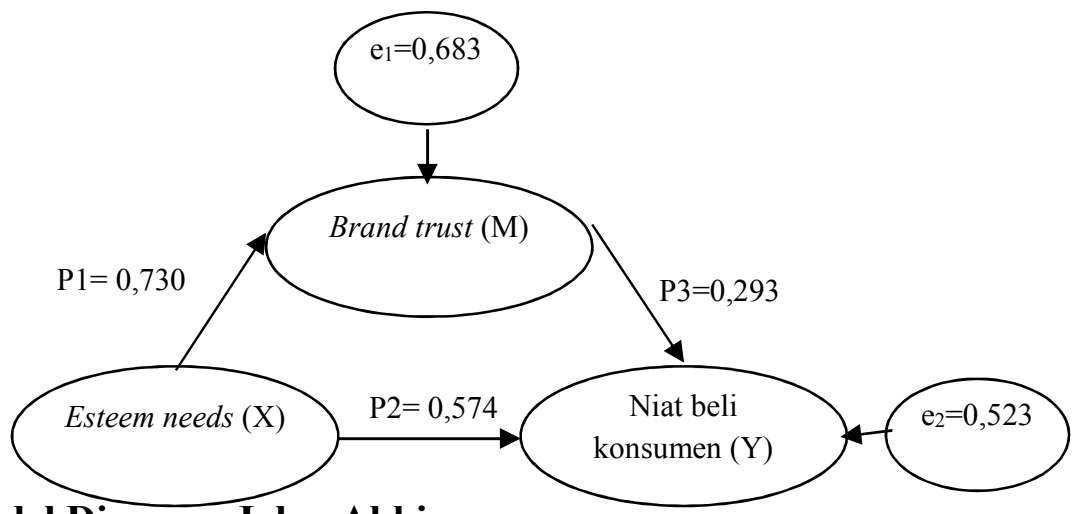

Sumber: Data Diolah, 2018

Gambar 3. memberikan petunjuk nilai koefisien jalur di model pengaruh esteem needs pada variable niat beli konsumen melewati brand trust. Berdasar kepada apa yang tercantum pada Gambar 3 dapat kita ketahui bahwasanya koefisien jalur pengaruh esteem needs pada variable niat beli konsumen sesudah variable brand trust dimasukkan didalam model memiliki nilai 0,347 tidaklah memiliki nilai 0 , yang mempunyai arti brand trust menjadi mediasi pengaruh positif esteem needs pada niat beli konsumen untuk barang Polo Ralph Lauren di Kota Denpasar.

Esteem needs (X) bisa dibuktikan memiliki pengaruh positif serta signifikan pada niat beli konsumen (Y), yang dapat ditampilkan oleh nilai koefisien jalur sejumlah 0,574, dengan tingkat signifikan ataupun $p$ value $=0,000$, yang mempunyai arti signifikansinya tinggi. Koefisien jalur mempunyai tanda positive, 
bisa diberikan arti bahwasannya peningkatan esteem needs yang dipunyai oleh pelanggan dapat menambah munculnya niat beli konsumen untuk barang-barang dari Polo Ralph Lauren di Kota Denpasar, sehingga hipotesa kedua yang menyatakan bahwa, esteem needs memiliki pengaruh positif serta signifikan pada niat beli konsumen untuk barang-barang Polo Ralph Lauren di Kota Denpasar bisa diterima.

Esteem needs $(\mathrm{X})$ dapat dibuktikan memiliki pengaruh positif serta signifikan brand trust $(\mathrm{M})$, yang ditampilkan oleh besaran koefisien jalur senilai 0,730 , dengan tingkat signifikannya ataupun $p$ value $=0,000$, yang mempunyai arti signifikansinya tinggi. Koefisien jalur mempunyai tanda positive, bisa diberikan arti bahwasannya peningkatan esteem needs yang dipunyai oleh pelanggan dapat menambah munculnya brand trust pelanggan untuk barang-barang Polo Ralph Lauren di Kota Denpasar, sehingga hipotesa pertama yang menyatakan bahwa, esteem needs memiliki pengaruh positif serta signifikan pada brand trust pelanggan untuk barang-barang Polo Ralph Lauren di Kota Denpasar dapat diterima.

Brand trust $(\mathrm{M})$ dapat dibuktikan memiliki pengaruh positif dan signifikan terhadap niat beli konsumen (Y), yang ditampilkan oleh besaran koefisien jalur senilai 0,293 , dengan tingkat signifikannya ataupun $p$ value $=0,000$, yang mempunyai arti signifikansinya tinggi. Koefisien jalur mempunyai tanda positive, bisa diberikan arti bahwasannya peningkatan brand trust yang dipunyai oleh pelanggan mampu memberikan dorongan munculnya niat beli konsumen untuk produk-produk Polo Ralph Lauren di Kota Denpasar, sehingga hipotesa ketiga yang menyatakan bahwa, brand trust memiliki pengaruh positif serta signifikan pada niat beli konsumen untuk barang-barang Polo Ralph Lauren di Kota Denpasar dapat diterima.

Brand trust (M) mampu menjadi mediasi dengan pengaruh positif esteem needs (X) pada niat beli konsumen (Y), yang ditampilkan oleh besaran koefisien jalur senilai 0,742 , dengan tingkatan signifikan ataupun $p$ value $=0,000$, yang mempunyai arti signifikansinya tinggi. Koefisien jalur mempunyai tanda positive, bisa diberikan arti bahwasannya brand trust bisa memberikan peningkatan esteem needs di diri pelanggan hingga memberikan peningkatan niat beli pada produkproduk Polo Ralph Lauren di Kota Denpasar dapat diterima, sehingga hipotesa keempat yang menyatakan, brand trust memediasi pengaruh positif esteem needs terhadap niat beli konsumen pada produk-produk Polo Ralph Lauren di Kota Denpasar dapat diterima.

Dari proses menghitung didapatkan besaran $\mathrm{z}$ hitung senilai $6,378>\mathrm{z}$ tabel senilai 1,96, sehingga Ho ditolak namun Hi diterima, hal ini berarti brand trust mampu menjadi mediasi pengaruh esteem needs pada niat beli konsumen untuk produk Polo Ralph Lauren di Kota Denpasar. Nilai determinasi total sejumlah 0,873 memiliki arti bahwasannya sejumlah $87,3 \%$ varians niat beli konsumen terpengaruhi oleh variable brand trust serta esteem needs, namu sisa sejumlah 12,7 persen mampu diberikan penjelasan oleh faktor-faktor lainnya yang tak masuk didalam model.

Berdasarkan hasil analisis regresi struktur 1, regresi struktur 2, dan regresi mediasi dengan perhitungan VAF, maka di dapat hasil sebesar 0,213. Nilai ini menunjukkan bahwa peran brand trust memediasi berpengaruhnya esteem needs 
pada niat beli konsumen secara parsial untuk produk-produk Polo Ralph Lauren di Kota Denpasar.

Hasil analis data esteem needs memberi pengaruh positif pada niat beli konsumen, dilihat dari esteem needs yang tinggi didalam diri pelanggan memberi sebuah pengaruh positif pada niat beli konsumen untuk produk-produk Polo Ralph Lauren di Kota Denpasar. Hasil riset tersebut sejalan dengan Deviana (2014) yang memberikan bukti variable harga diri ataupun esteem needs bisa memberi pengaruh positive pada niat beli konsumen. Harga diri ataupun esteem needs yang dipunyai pelanggan memberi pengaruh positif dan signifikan pada niat beli konsumen untuk barang maupun jasa (Amsyah, 2010). Niat beli orang dapat diberikan pengaruh secara positif signifikan dengan adanya harga diri ataupun esteem needs yang mereka punya (Hung et al., 2011). Berbeda dengan riset lainnya yang menyatakan bahwa niat beli konsumen tidak diberikan pengaruh dengan adanya esteem needs yang dimiliki konsumen (Hanzaee \& Taghipourian, 2012). Hal yang sama diungkapkan oleh penelitian lain yang menyatakan esteem needs tidak memiliki pengaruh positif pada niat beli konsumen (Dehdashti Shahrokh \& Deilami Azodi, 2013).

Berdasarkan hasil analisis data diketahui bahwa esteem needs terhadap brand trust berpengaruh signifikan positif. Hal ini mengandung arti bahwa semakin tinggi kebutuhan atau esteem needs seseorang pelanggan pada Kota Denpasar memiliki akibat positif untuk brand trust pelanggan dalam pembelian produk-produk Polo Ralph Lauren. Hasil riset berikut didukung oleh penelitian sebelumnya menyatakan bahwa esteem needs berpengaruh positif terhadap brand trust konsumen (Hanzaee \& Taghipourian, 2012). Ayu dan Kerti (2014) menyatakan bahwa brand trust memiliki hubungan positif terhadap esteem needs. Penelitian lainnya juga menyatakan bahwa esteem needs berpengaruh positif terhadap brand trust (Dehdashti Shahrokh \& Deilami Azodi, 2013). Berbeda dengan penelitian di tahun 2014 yang memperoleh hasil brand trust tidak dipengaruhi oleh esteem needs dari diri konsumen (Goenawan, 2014). Hal yang sama diungkapkan oleh penelitian di tahun 2007 yang menyatakan brand trust memiliki hubungan positif terhadap esteem needs (Setyaningsih et al., 2007).

Berdasarkan kepada hasil analisa data dapat kita ketahui bahwasannya brand trust pada niat beli konsumen memiliki pengaruh signifikan positif. Pernyataan tersebut berarti bahwasannya makin tingginya brand trust seseorang pelanggan di Kota Denpasar dapat memberi akibat positif untuk niat beli konsumen dalam pembelian produk-produk Polo Ralph Lauren.

Hasil riset tersebut didukung oleh penelitian sebelumnya yang mendapatakan brand trust yang mereka terapkan bisa memberi akibat yang positive serta signifikan didalam membentuk niat beli konsumen (Sudomo, 2013). Pernyataan yang sama dinyatakan oleh penelitian lainnya yaitu brand trust pada konsumen mampu menciptakan dampak positive signifikan pada niat beli konsumen (Wibisono, 2012). Pernyataan yang sejalan juga diungkapkan oleh Andrie dan Harold (2013) brand trust pada suatu produk memberikan pengaruh positif terhadap niat beli konsumen. Berbeda dengan penelitian lainnya dimana hasil yang didapatkan yaitu niat beli konsumen tidak dipengaruhi oleh brand trust dari suatu merek (Goenawan, 2014). Hal yang sama diungkapkan oleh penelitian di tahun 
2007 yang menyatakan brand trust tidak berpengaruh positif terhadap niat beli konsumen (Setyaningsih et al., 2007).

Berdasarkan hasil analisa data bias kita ketahui bahwasannya brand trust mampu menjadi mediasi pengaruh esteem needs pada niat beli konsumen dengan positive. Pernyataan tersebut berarti bahwasannya makin tingginya esteem needs seseorang pelanggan di Kota Denpasar memberikan akibat positive dengan esteem needs konsumen hingga memberikan peningkatan niat beli konsumen dalam melakukan pembelian produk-produk Polo Ralph Lauren di Kota Denpasar.

Hasil riset tersebut sejalan dengan riset lainnya yang menyatakan niat beli konsumen sangatlah diberikan pengaruh dengan positif serta signifikan dengan adanya esteem needs ataupun harga diri pelanggan sesuai munculnya kepercayaan atau brand trust pada suatu barang atau jasa (Darmasari \& Wijayanto, 2014). Deviana (2014) memberikan bukti hasil yang sesuai dengan ada tidaknya kepercayaan ataupun brand trust bisa memberi pengaruh positif dan signifikan antara hubungan esteem needs dengan niat beli konsumen untuk barang atau jasa. Penelitian lainnya menyatakan bahwa pengaruh positif esteem needs dengan niat beli konsumen pada produk terbentuk dengan moderasi oleh kepercayaan ataupun brand trust pada sebuah produk (Hanzaee \& Taghipourian, 2012). Berbeda dengan penelitian di tahun 2014 yang menyatakan niat beli konsumen dipengaruhi oleh esteem needs tidak diperkuat oleh brand trust (Goenawan, 2014). Hal yang sama diungkapkan oleh Rahmawati di tahun 2007 menyatakan esteem needs memiliki hubungan positif terhadap niat beli konsumen yang tidak diperkuat oleh brand trust (Setyaningsih et al., 2007).

\section{SIMPULAN}

Berdasar kepada pembahasan di bab yang sebelum-sebelumnya, jadi ada beberapa hal yang bisa tersimpulkan adalah esteem needs berpengaruh positif dan signifikan terhadap niat beli konsumen pada pakaian Polo Ralph Lauren di Kota Denpasar. Esteem needs berpengaruh positif dan signifikan terhadap brand trust konsumen pada pakaian Polo Ralph Lauren di Kota Denpasar. Brand trust berpengaruh positif dan signifikan terhadap niat beli konsumen pada pakaian Polo Ralph Lauren di Kota Denpasar. Brand trust memediasi pengaruh positif esteem needs terhadap niat beli konsumen pada pakaian Polo Ralph Lauren di Kota Denpasar.

Berdasar kepada simpulan, beberapa saran yang bisa diberi sebagai distributor produk Polo Ralph Lauren di Kota Denpasar haruslah lebih gencar memberikan penawaran barang atau jasa yang cocok dengan melihat keperluan serta memberi peningkatan esteem needs yang dipunya pelanggan. Oleh karena hal tersebut produsen Polo Ralph Lauren haruslah memberikan perhatian posisi serta pandangan pelanggan akan berguna tidaknya sebuah barang atau jasa hingga jadi inspirasi juga memberikan peningkatan esteem needs pada masyarakat. Sebagai distributor pakaian Polo Ralph Lauren di Kota Denpasar harus memperhatikan kepercayaan merek yang diberikan kepada konsumen di Kota Denpasar, dimana produsen Polo Ralph Lauren memberikan peningkatan info tentang kelebihan daripada produk-produk Polo Ralph Lauren hingga pelanggan merasakan 
kenyamanan, kepercayaan diri, ketertarikan serta dengan pasti akan memilih Polo Ralph Lauren sebagai produk yang dipercayai dan dibutuhkan.

\section{REFERENSI}

Amsyah, J. W. (2010). Pengaruh gengsi, kepuasan, dan komunikasi perusahaan terhadap word of mouth dan niat beli kembali dengan variabel antara identifikasi merk (kasus pada produk Blacberry di Surabaya). Jurnal Ekonomi Erlangga. 2(6), 1-128.

Darmasari, R., \& Wijayanto, G. (2014). Pengaruh Brand Equity Dalam Membentuk Lifestyle Dan Customer Value Pada Pengguna Merek Smartphone Di Kota. Jurnal Tepak Manajemen Bisnis, VI(2), 86-98.

Dehdashti Shahrokh, Z., \& Deilami Azodi, A. (2013). The Effect of Country of Origin Image on Brand Equity and Purchase Intention. J. Appl. Environ. Biol. Sci, 3(12), 52-61.

Deviana Wijoyo, (2014). Pengaruh Consumer Excitiment, Consumer Esteem dan Impulse Buying Intention Terhadap Impulse Buying Behavior Pada Konsumen Hypermarket Ciputra World Surabaya. Jurnal Manajemen dan Bisnis. 3(1), 1-7

Ghozali, Imam, (2011), Aplikasi Analisis Multivariat/2, Badan Penerbit Undip, Semarang

Goenawan, K. (2014). Pengaruh product attributes, brand name, product price, dan social influence terhadap purchase intention android smartphone di surabaya, 3(1), 1-17.

Hair,J,J,F,. Hult, G, T, M,. Ringle, C, M,. and Sarstedt, M. (2014). A Primer On Partial Least Squares Structural Equation Modeling PLS-SEM). United States Of America : Sage Publications Ltd.

Hanzaee, K. H., \& Taghipourian, M. J. (2012). The Effects of Brand Credibility and Prestige on Consumers Purchase Intention in Low and High Product Involvement The Effects of Brand Credibility and Prestige on Consumers Purchase. Journal of Basic and Applied Scientific Research, 2(2), 12811291.

Hung, K. peng, Chen, A. H., Peng, N., Hackley, C., Tiwsakul, R. A., \& Chou, C. lun. (2011). Antecedents of luxury brand purchase intention. Journal of Product and Brand Management, 20(6), 457-467. https://doi.org/10.1108/10610421111166603

Kotler, P. dan Keller, K.L. (2007). Manajemen Pemasaran, Cet 2, Edisi 12, Jilid 1, Alih bahasa: Benyamin Molan. Penerbit PT INDEKS.

Kotler, Philip and G. Armstrong. (2012). Principles of Marketing. 14th ed. New Jersey: Prentice Hall. 
Kuenzel, Sven \& Sue Vaux Halliday. (2008). Investigating Antecedents and Consequences of Brand Identification. Journal of Product \& Brand Management. 4(2), 293-304

Mowen, J. dan Minor, M. (2007). Perilaku Konsumen. Jakarta : Erlangga

Maoyan, Zhujunxuan, dan Sangyang, (2014). Consumer Purchase Intention Research Based on Social Media Marketing. International Journal of Business and Social Science. 5(10), 92-97

Nick Hajli, M., (2013). A study of the impact of social mediaon consumers. International Journal of Market Research. 56(3), 387-404

Parisa Valavi, (2014). Factors Influencing Mobile Services Adoption: A BranEquity Perspective. International Journal of Research Social Sciences. 4(3), $1-18$

Pavlou, P.A. (2003). "Consumer Acceptance of Electronic Commerce : Integrating Trus and Risk With The Technology Acceptance Model. International Technology. 14(1), 39-52

Prabhawedasattya, I Gusti Ayu Putri Anggrihita., dan Kerti Yasa, Ni. Nyoman. (2014). Pengaruh ekuitas merek terhadap preferensi merek dan niat beli konsumen pada produl Iphone di Kota Denpasar. Jurnal Manajemen Ekonomi. 16(1), 1525-1551

Rahizah Abd Rahim, Farah Waheeda Jalaludin and Kasmah Tajuddin, (2011).The Importance of Corporate Social Responsibility on Consumer Behavior in Malaysia. Asian Academy of Management Journal. 16(1), 119-139

Rizy Darmawan dan I Nyoman Nurcaya. (2018). Membangun Niat Beli Iphone melalui Ewom dan Brand Image. E-Jurnal Manajemen Unud 7(9), 51685196

Saadia Shabnam. (2013). Proposed Model for Predicting Environmental Purchase Behavior of Consumers. Journal European Academic Research. 1(4), 444466

Santoso, Singgih. (2010). Buku Latihan SPSS Statistik Parametrik. Jakarta : Alex Media Komputindo.

Setyaningsih, R., Mangunwihardjo, S., \& Soesanto, H. (2007). Analisis FaktorFaktor Yang Mempengaruhi Ekuitas Minat Beli Ulang ( Studi Kasus Pada Kedai Kopi Dôme Di Surabaya ), 4, 30-43. Retrieved from http://eprints.undip.ac.id/18818/

Sreejesh, S., (2015). Consumers' Perceived Brand Aspiration and Its Impact on Intention to Pay Price Premium: Moderating Role of Brand Jealousy. Journal Theoretical Economics Letters. 5(1), 273-284 
Pauline Geethruida Liwe, Pengaruh Esteem Needs.....

Sudomo, S. (2013). Pengaruh Ekuitas Merek terhadap Keputusan Pembelian, I(2), 48.

Sugiyono, (2010). Metode Penelitian Bisnis. Cetakan Ke-15. Penerbit Alfabeta. Bandung.

Suprapti, Ni Wayan Sri. (2010). Prilaku Konsumen, Pemahaman Dasar dan Aplikasinya Dalam Strategi Pemasaran. Bali : Udayana University Press.

Suyana Utama, Made. (2009). Buku ajar Aplikasi Analisis Kuantitatif. Denpasar :Fakultas Ekonomi Universitas Udayana

Tae Hyun Baek and Jooyoung Kim and Jay Hyunjae Yu, (2010). The Differential Roles of Brand Credibility and Brand Prestige in Consumer Brand Choice. Journal Psychology \& Marketing. 27(7), 662-678

Tanya Ryan, (2014). Green Intentions: An Exploratory Study on Advertising and the Environmental Movement. Journal of research for Consumers. 27(7), 76-105

Wibisono, Y. H. (2012). Faktor-faktor yang mempengaruhi perilaku pembelian dengan perilaku niat sebagai variabel intervening pada situs kaskus.Surabaya: Universitas Katolik Widya Mandala., 2012. 